\title{
In vitro germination of zygotic embryos excised from cryopreserved endocarps of queen palm (Syagrus romanzoffiana (Cham.) Glassman)
}

\author{
Izulmé Rita Imaculada Santos ${ }^{1}$ - Antonieta Nassif Salomão ${ }^{1}$
}

Received: 17 January 2017 / Accepted: 26 June 2017 / Published online: 9 August 2017 / Editor: Barbara Reed

(C) The Society for In Vitro Biology 2017

\begin{abstract}
Queen palm (Syagrus romanzoffiana [Cham.] Glassman) is a palm species best known as an ornamental tree for urban landscaping, but recently, it has been evaluated as a potential crop for biofuel production. The objective of the present work was to establish a cryopreservation technique for queen palm to ensure long-term conservation of this species. The cryopreservation protocol consisted of direct immersion in liquid nitrogen (LN) of whole endocarps with water contents ranging from 5.5 to $10.9 \%$, followed by slow thawing at room temperature $\left(25 \pm 2^{\circ} \mathrm{C}\right)$ excision and in vitro culture of zygotic embryos. Viability of zygotic embryos isolated from endocarps with different water contents was evaluated before (control) and after freezing in LN using in vitro culture on Woody Plant Medium (WPM) medium. Germination percentages of zygotic embryos isolated from endocarps stored in LN varied from 84 to $93 \%$, whereas those isolated from controls ranged from 55 to $71 \%$. Germination rates were significantly higher for zygotic embryos excised from cryopreserved endocarps. The water content of control or frozen endocarps did not have a significant effect on germination percentages of zygotic embryos. Zygotic embryos excised from endocarps following cryopreservation in liquid nitrogen developed into normal plantlets after in vitro culture. The technique tested is simple, efficient, and can be used in plant gene banks as a routine approach for long-term conservation of queen palm germplasm.
\end{abstract}

Izulmé Rita Imaculada Santos

izulme.santos@embrapa.br

1 Embrapa Recursos Genéticos e Biotecnologia (Embrapa Genetic Resources and Biotechnology), Parque Estação Biológica (PqEB), Avenida W5 Norte, final, S/N, Asa Norte, CEP,

Brasília, DF 70770-917, Brazil
Keywords Cryopreservation · Zygotic embryos · Queen palm $\cdot$ Syagrus romanzoffiana

\section{Introduction}

Queen palm (Syagrus romanzoffiana [Cham.] Glassman) is a perennial palm tree of the Arecaceae family widely distributed in South America in tropical and subtropical areas (Glassman 1987; Begnini et al. 2013). This species has many uses. It is a popular ornamental tree in urban landscaping due to its beautiful appearance and low maintenance requirements. The tree is also a source of edible palm hearts (apical meristem and undifferentiated leaves) that are consumed as a gourmet vegetable, of fruits that are sought by birds and small mammals, and of leaves that are used as feed for cattle (Galetti et al. 1992; Lorenzi et al. 1996; Lorenzi 2002). More recently, there has been increasing interest in using this species for biofuel production due to the high lipid content of the endosperm, which can exceed 50\% (Moreira et al. 2013). Another important trait of the queen palm is that it can grow in many different types of environments, even dry areas, producing abundant fruits throughout the year.

The queen palm produces fleshy fruits, that become bright orange, juicy, and sweet when ripe and that consist of a thin layer of fibrous flesh (mesocarp), a woody endocarp, and a single seed generally with one embryo (Goudel et al. 2013). The main propagation method of the species is sexual through seed germination. However, seedling production is limited by uneven seed germination, slow seedling emergence, and high seed loss due to deterioration (Goudel et al. 2013). Studies on longevity and germination patterns of stored queen palm seeds indicate that they are short lived, with uncertain storage behavior. Seed germination percentages decrease to very low levels after storage under laboratory conditions, most likely 
due to loss of embryo vigor and deterioration caused by crystallization of lipids of the seed endosperm (Balesevic-Tubic et al. 2010; Goudel et al. 2013; Oliveira et al. 2015). Therefore, preservation and conservation of $S$. romanzoffiana via orthodox seed storage methods is not feasible (Sturião et al. 2012; Goudel et al. 2013; Oliveira et al. 2015).

There is increasing interest in the development of effective protocols for germplasm preservation of palm species in general and of S. romanzoffiana in particular (Kaviani 2011). However, presently ex situ conservation of queen palm accessions can only be implemented through establishment of germplasm collections in field gene banks, which exposes plants to many threats and is not a long-term conservation strategy (Kaviani 2011). In cases like this, cryopreservation in liquid nitrogen (LN) has been appointed as the most promising alternative strategy for long-term storage of valuable plant germplasm. Cryopreservation involves storage of plant material at ultra-low temperatures in liquid nitrogen $\left(-196^{\circ} \mathrm{C}\right)$, and at this temperature, cell division and metabolic activities are suspended and the samples can be stored without changes for long periods of time. It requires limited space, protects samples from contamination, requires very little maintenance, and is a cost-effective option for plant genetic resources conservation.

Embryo culture in vitro has been used in seed conservation as an alternative, rapid method of assessing seed quality or to recover growth of difficult-to-store seeds, and generally, there is a good correlation between embryo growth in vitro and germination percentages (Pritchard et al. 2000). Cryopreservation of seeds and zygotic embryos was previously used as an alternative strategy for long-term conservation of many plant species (Pritchard et al. 2000; González-Benito et al. 2009; Santos and Salomão 2016). In the case of palms, cryopreservation protocols have been developed for seeds and embryos of different species (Grout et al. 1983; Chin et al. 1988; Assy-Bah and Engelmann 1992; Engelmann et al. 1995; Raja et al. 2003; Steinmacher et al. 2007; N'Nan et al. 2012). However, there is no report of cryopreservation of queen palm germplasm.

The objective of this study was to establish a cryopreservation technique for queen palm endocarps to ensure longterm conservation of this species. This paper describes the effect of water content and storage in LN on both in vitro germination of queen palm zygotic embryos and seedling development. This is the first report on cryopreservation of S. romanzoffiana germplasm.

\section{Materials and Methods}

Plant material Mature fruits of queen palm [S. romanzoffiana (Cham.) Glassman] were collected from trees growing in
Brasília, Federal District, Brazil, and taken to the laboratory at Embrapa Genetic Resources and Biotechnology, in the same locality. Fruits were processed immediately to remove the juicy pulp (mesocarp) surrounding the endocarps first using a blender and subsequently by rubbing fruits across a metal mesh sieve. Endocarps were washed with a sodium hypochlorite solution [2 to $2.5 \%$ active chlorine, Qboa ${ }^{\circledR}$, Indústrias Anhembi Ltda, Osasco, SP, Brazil) containing five to eight drops (300 to $500 \mu \mathrm{L}$ ) of commercial grade detergent (Ypê, Química Amparo Ltda, São Paulo, SP, Brazil) and then rinsed thoroughly under running tap water until all visible traces of the fibers had been removed. Endocarps were spread out on the laboratory bench covered with sheets of germination paper, at room temperature $\left(25 \pm 2^{\circ} \mathrm{C}\right)$, where they were maintained for $24 \mathrm{~h}$ to dry. Three replicates containing $15 \mathrm{de}-$ pulped (mesocarp removed) endocarps were used in all the tests carried out in this study.

Water content determination and adjustment The initial water content (WC) of freshly harvested (FH), de-pulped, endocarps was determined by the oven method (Brazilian Ministry of Agriculture Livestock and Supply 2009) using a sample of 15 endocarps $(3 \times 5)$ and calculated on a fresh weight basis (FWB). Afterwards, the WC of endocarps was adjusted to four moisture levels using dehydration or hydration. For dehydration, endocarps were placed inside a plastic container and covered with $200 \mathrm{~g}$ of blue silica gel (commercial grade, Vetec $\AA$, ref. 155, Rio de Janeiro, RJ, Brazil) before the container was closed with its lid and kept in a germinator for $24 \mathrm{~h}$, in darkness, at a constant temperature of $25 \pm 2{ }^{\circ} \mathrm{C}$. For hydration, endocarps were placed over the nets of an acrylic germination box (Gerbox ${ }^{\circledR}$, São Paulo, SP, Brazil) containing $200 \mathrm{~mL}$ of distilled water before the box was covered with its lid and kept in a germinator (Eletrolab®, São Paulo, SP, Brazil) for $24 \mathrm{~h}$, in darkness, at constant temperature $\left(25 \pm 2^{\circ} \mathrm{C}\right)$ for 21,24 , or $48 \mathrm{~h}$. Water content of dehydrated and hydrated endocarps was determined by the oven method as described previously.

Freezing and thawing For freezing, endocarps of different WC were transferred to trifoliate envelopes (Moore and Buckle, Ltd., St. Helens, UK), heat sealed, transferred to canisters, and submerged in LN for 6 mo. Thawing was done by removing the samples from the cryotank and maintaining them at $25 \pm 2^{\circ} \mathrm{C}$ for at least $4 \mathrm{~h}$.

Zygotic embryo excision and in vitro culture Viability of zygotic embryos (ZEs) excised from endocarps with different WC was assessed before and after freezing in LN by means of in vitro germination. Information on in vitro culture of $S$. romanzoffiana ZE is scarce, so a preliminary test was carried out to test two culture media: Murashige and Skoog (1962) (MS) and Woody Plant Medium (WPM) (Lloyd and 
McCown 1981). ZE cultivated on WPM (data not shown) medium showed the best germination results; therefore, this medium was used in all the remaining experiments. For each WC level, $45(3 \times 15)$ ZEs were excised from control endocarps and $45(3 \times 15)$ ZEs were excised from endocarps stored in LN. Before excision of ZE, endocarps (controls and frozen) were decontaminated to avoid contamination during in vitro culture with a sodium hypochlorite solution (2.0 to $2.5 \%$ active chlorine, Indústrias Anhembi Ltda) containing 8-10 drops (500 to $625 \mu \mathrm{L})$ of commercial grade detergent and 58 drops (300 to $500 \mu \mathrm{L}$ ) of Tween ${ }^{\circledR} 20$ (P7949, SigmaAldrich ${ }^{\circledR}$, St. Louis, MO) for $15 \mathrm{~min}$, under constant agitation in a rotary shaker. In the laminar flow hood, endocarps were rinsed three times with sterile, distilled water. All endocarps were hydrated by adding $100 \mathrm{~mL}$ of sterilized distilled water to the endocarps before they were transferred to a seed germinator, in darkness, at a constant temperature of $25 \pm 2^{\circ} \mathrm{C}$ for $48 \mathrm{~h}$. After hydration treatment, endocarps were cracked using a sterilized bench-top vise in the laminar flow hood to extract the seeds. A whole ZE (3 to $5 \mathrm{~mm}$ long) was excised from each seed. After excision, individual ZEs were placed into $25 \times 150 \mathrm{~mm}$ glass test tubes (Uniglass, Piracicaba, SP, Brazil) containing $10 \mathrm{~mL}$ of WPM. The WPM contained $30 \mathrm{~g} \mathrm{~L}^{-1}$ sucrose and $3 \mathrm{~g} \mathrm{~L}^{-1}$ activated charcoal, added to prevent browning of $\mathrm{ZE}$ during culture, and solidified with $7.0 \mathrm{~g} \mathrm{~L}^{-1}$ plant cell culture-tested agar (A1296, Sigma-Aldrich ${ }^{\circledR}$ ). All chemicals used in the medium composition were made by Sigma-Aldrich ${ }^{\circledR}$ Chemicals Co. and purchased in Brazil, from a local representative. The $\mathrm{pH}$ of the medium was adjusted (by adding $1.0 \mathrm{~N} \mathrm{NaOH}$ solution) to 5.8 before the addition of agar and before sterilization by autoclaving at $121^{\circ} \mathrm{C}$ and $100 \mathrm{kPa}$ of pressure for $20 \mathrm{~min}$. All cultures were maintained in a growth room at $25 \pm 2^{\circ} \mathrm{C}$ and 12-h photoperiod of $50 \mu \mathrm{mol} \mathrm{m} \mathrm{m}^{-1}$ light intensity provided by cool white fluorescent tubes (Sylvania, daylight plus FHO85 WT12®, Sylvania Brasil Iluminação, São Paulo, SP, Brazil) and were observed weekly up to 4 mo to detect and record germination events. After 4 mo of culture in vitro, final germination percentages were recorded. The germination criterion adopted was the development of normal seedlings (those presenting coleoptile, main root, first leaf, and leaf sheath) as described by Bernacci et al. (2008).

Statistical analysis All experiments were carried out with three replicates for each treatment. To assess the effects of different water contents and freezing on germination of ZE, a binomial distribution was made using generalized linear models (GLMs) to generate an analysis of deviance table (ANODEV). When the ANODEV factors were significant, the unfolding of degrees of freedom was performed by orthogonal contrasts to obtain comparisons of interest (McCullagh and Nelder 1989). All analyses were conducted using the statistical language program R by GLM function, at a $5 \%$ significance level. The statistical programs GraphPad Prism (@2017 GraphPad Software Inc.) and R (free access) were used for the statistical analysis and graphing of the data.

\section{Results and Discussion}

In order to establish a cryopreservation technique for queen palm S. romanzoffiana, endocarps, at four levels of water content, were stored in $\mathrm{LN}$ and then thawed for ZE excision. The effects of LN storage and thawing on germination and subsequent in vitro seedling development were studied.

The fresh fruits were oval shaped and $25 \mathrm{~mm}$ or less in length and with an average diameter of 21 to $22 \mathrm{~mm}$ (Fig. $1 A)$. The fleshy mesocarp was removed to reveal the hard endocarp which generally contains a single seed (Fig. $1 B$ ). Queen palm seeds are curved, have a tegument lining the endosperm, and are attached to the endocarp by a pronounced recess, which makes their removal without damage very difficult (Fig. 1C). Embryos are typically cylindrical, white, and very tender and measure 4.0 to $5.0 \mathrm{~mm}$ on average in length and about $1 \mathrm{~mm}$ in width (Fig. 1D). Handling small and delicate ZE such as these increases the possibility of mechanical injury, compromising their integrity and capacity for growth (Pritchard et al. 2000). For this reason, the initial plan was to use whole seeds as the experimental unit for this study, as has been done for other palm species (Engelmann et al. 1995). However, extraction of whole seeds from the woody endocarps proved very challenging, and most seeds were crushed in the attempt. Previous studies reported that queen palm endocarps are water permeable and that seeds are able to gain or lose water even inside the endocarps (Baskin and Baskin 2014; Oliveira et al. 2015). For this reason, whole endocarps were used as the experimental unit in all the tests carried out in this study. This choice also simplified the procedure, which makes it more practical for routine use in gene banks.

Water content is a critical factor in the maintenance of plant cell viability and integrity after cryopreservation, since high levels of water in the cells will result in the formation of destructive ice crystals upon freezing (Reed 2008; Ferrari et al. 2016). However, seeds of many palm species show recalcitrant storage behavior and do not tolerate drying or storage at subzero temperatures (Goudel et al. 2013). Although the storage behavior of queen palm seeds has not been thoroughly assessed, previous work showed a consistent decline in seed water content through maturation and that seeds can still germinate after desiccation to $12.7 \%$ of the initial water content, a level considered lethal for the germination of many palm species. These results indicate that queen palm seeds are tolerant of partial drying and their storage behavior might be classified as intermediate (Brancalion et al. 2011; Goudel et al. 2013; Oliveira et al. 2015). 

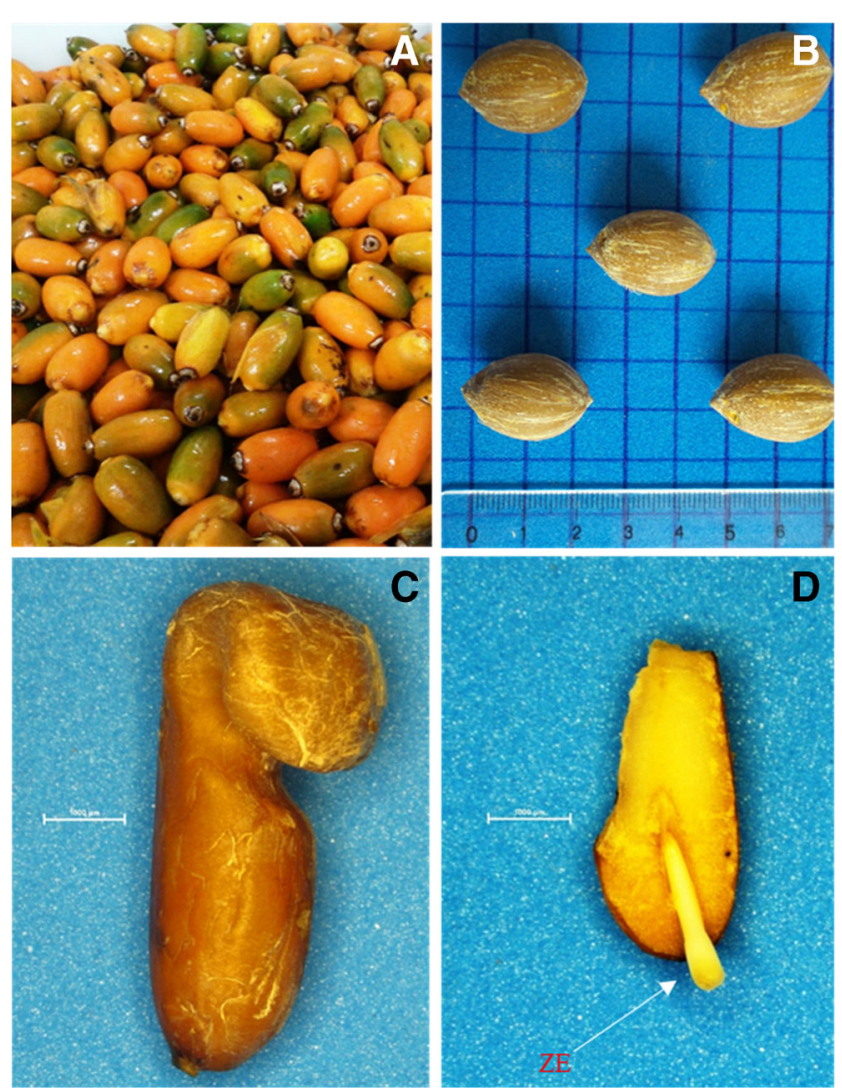

Figure 1. Fruit anatomy of the queen palm, Syagrus romanzoffiana (Cham.) Glassman. (A) Freshly harvested whole fruits. (B) Whole endocarp. (C) Whole seed excised aseptically from the endocarp. $(D)$ Cylindrical zygotic embryo (ZE) still attached to the seed. Whole endocarps $(B)$ of different water contents were the structures cryopreserved in liquid nitrogen.

The effect of water content on germination of control and cryopreserved ZE was assessed to find an optimal water content to prevent freezing damage. The water content of endocarps was adjusted to $5.5 \%$ by dehydration with silica gel or to 10.52 or $10.87 \%$ by hydration over $100 \mathrm{~mL}$ of distilled water. Silica gel efficiently promoted desiccation of endocarps and caused a marked reduction in WC (Fig. 2). N'Nan et al. (2012) pointed out that the use of silica gel ensures more precise and reproducible dehydration, allowing standardization of the method.

The results observed indicate that the WC of the endocarp did not have a significant effect on germination percentages of either control or cryopreserved ZE (Table 1 and Fig. 2). In control endocarps, the germination percentages of the excised ZE ranged from 55 to $71 \%$ (Fig. 2,- LN). These results are in agreement with those observed during the assessment of the effect of partial drying on germination of $S$. romanzoffiana seeds (Goudel et al. 2013), wherein queen palm seeds dehydrated to $12.7 \% \mathrm{WC}$ remained viable, showing germination rates, germination speed index, and radicle lengths similar to those of control seeds ( $20.2 \% \mathrm{WC}$ ). The authors concluded that seeds of this species are more tolerant of partial drying

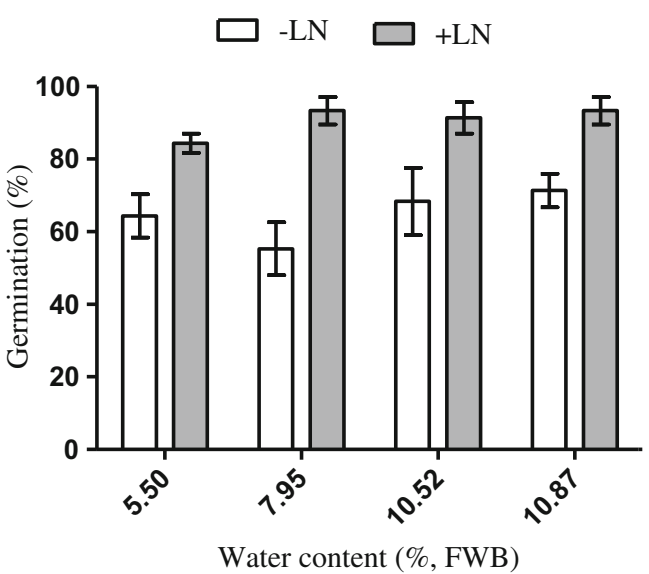

Figure 2. In vitro germination of zygotic embryos of $S$. romanzoffiana excised from endocarps dried at $25 \pm 2{ }^{\circ} \mathrm{C}$ to different water content (WC) levels and cryopreserved $(+\mathrm{LN}$, filled) or not $(-\mathrm{LN}$, empty). Values presented are the percentage of ZE germinated on WPM culture medium and represent means \pm standard error (SE) of three replicates of 15 embryos. These values only include seedlings with normal morphology, that is, with a plumule, haustorium, and root system and without fungal contamination. WC values presented were calculated on a fresh weight basis (FWB).

than those of many other palm species. Oliveira et al. (2015) also reported that freshly harvested queen palm seeds dried to $5 \% \mathrm{WC}$ remained viable, although there was a marked decrease in germination after these seeds were stored for $2 \mathrm{y}$ in a cold chamber at $5^{\circ} \mathrm{C}$. It is a general view that the significant reductions in viability and vigor of $S$. romanzoffiana seeds are not due to water loss, but rather to deterioration of the seed due to the high lipid content of the endosperm (Goudel et al. 2013; Oliveira et al. 2015). However, further studies are necessary to elucidate this matter.

Storage in LN caused a significant improvement $(P<0.001)$ in ZE germination (Fig. $2,+\mathrm{LN})$. The germination percentages of ZE excised from cryopreserved endocarps were higher than the unfrozen controls, ranging from 84 to 93\% depending on WC (Fig. 2, $+\mathrm{LN}$ ). These germination percentages are much higher than the percentages observed after cryopreservation of palm species reported elsewhere. For instance, a comparison of two cryopreservation strategies for oil palm showed that only $25 \%$ of ZE excised from whole cryopreserved endocarps remained viable (Engelmann et al. 1995). These germination percentages are much lower than the percentages obtained in the present study for queen palmcryopreserved endocarps. Additionally, the germinated ZEs of queen palm were able to develop into whole, true-to-type plantlets, which was not observed in the study with oil palm. This might be an indication that ZEs of queen palm are more tolerant of desiccation, freezing, or both.

This increase in germination percentages is most likely an indirect effect of freezing. It is possible that the freezing or thawing, and associated changes in vapor pressure, caused micro-fissures in the endocarps, which facilitated hydration 
Table 1. Significance (5\% level) of the variables tested, and of their interaction, on germination percentages and on development of seedlings of $S$. romanzoffiana $\mathrm{ZE}$ in vitro

\begin{tabular}{lllrc}
\hline Treatment & Likelihood ratio $\left(\chi^{2}\right)$ & Degrees of freedom & $F$ & $P=0.05$ \\
\hline Cryopreservation & 3978.4 & 1 & 42.3983 & $<0.001$ \\
Water content & 292.1 & 3 & 1.0377 & 0.4025 \\
Interaction & 307.1 & 3 & 1.0910 & 0.3814 \\
\hline
\end{tabular}

Analysis of deviances (ANODEV) obtained from the normal model with logarithmic link function $(\mathrm{AIC}=185.3744)$ and, subsequently, better cracking with a bench vise during the excision of the ZE. Hydration of both the frozen and control endocarps prior to $\mathrm{ZE}$ excision was essential to soften and facilitate breaking them with the vise, thus preventing crushing of the embryo as they ruptured. In a study of the morphogenetic potential of excised palm embryos in vitro, Zaid and Tisserat (1984) also reported soaking palm seeds for $48 \mathrm{~h}$ to soften them and facilitate embryo excision. Due to endocarp cracking and excision procedures, embryos can suffer mechanical injury, which triggers browning due to oxidation of phenolic compounds and, consequently, reduction in embryo germination percentages (Wen and Wang 2010). A similar effect of LN was proposed during a study of the influence of moisture content on cryopreservation of Coffea and Vigna seeds and embryos (Normah and Vengadasalam 1992). They hypothesized that storage in LN removed physical dormancy by inducing a network of cracks in or otherwise disrupting the structures surrounding the seed, such as the endocarp (Normah and Vengadasalam 1992), or the embryo, such as the seed coat (Busse 1930; Brant et al. 1971). This hypothesis is reinforced by results obtained in a study of other species whose seeds are enclosed by woody endocarps (Buchenavia tomentosa, Byrsonima basiloba, and Guettarda pohliana, and, more remarkably, with Schinopsis brasiliensis and Spondias mombin), in which the final germination percentages after LN treatment increased in comparison to those of controls (Salomão 2002). Hydration of queen palm endocarps has a significant effect on seed germination, and seeds soaked in water for $24 \mathrm{~h}$ before germination tests showed higher scores for normal seedling development, radicle length, and germination speed index (Goudel et al. 2013).

Cryopreservation has been reported previously for other palm species, such as Areca catechu (Raja et al. 2003), Cocos nucifera (Chin et al. 1989; Assy-Bah and Engelmann 1992), Bactris gasipaes (Steinmacher et al. 2007), Elaeis guineensis (Engelmann et al. 1995), Sabal spp. (Wen and Wang 2010), and Veitchia merrilli and Howea fosteriana (Chin et al. 1988). Steinmacher et al. (2007) reported successful cryopreservation of peach palm ZE using the encapsulation-dehydration method; however, in this case, only $29 \%$ of the embryos survived exposure to liquid nitrogen. For four Sabal species, pre-incubation combined with dehydration to 18 to $20 \% \mathrm{WC}$, direct freezing, and rapid thawing was the best approach to ensure 31 to $44 \%$ embryo survival
(Wen and Wang 2010). Mature excised embryos of four coconut varieties could withstand cryopreservation in LN and then develop into normal plantlets after air desiccation for $4 \mathrm{~h}$ followed by 11 to $20 \mathrm{~h}$ of culture on medium with glucose and glycerol, achieving 33 to $93 \%$ recovery (Assy-Bah and Engelmann 1992). Raja et al. (2003) reported that excised embryonic axes of $A$. catech $u$ with a water content of $21.8 \%$ showed $70 \%$ survival after cryopreservation. In all these cases, the embryos or embryonic axes were excised before the cryopreservation procedures. Isolated embryo cryopreservation is necessary in many cases to allow better adjustment of water content or to avoid germination difficulties due to dormancy or other problems imposed by the surrounding structures. However, manipulations of isolated embryos may further increase the complexity of and difficulty in the development of a cryopreservation method. Mechanical damage during embryo excision is very likely to occur, and even minor injuries can lead to tissue browning due to oxidation of phenolic compounds (Pritchard et al. 2000). Another factor to consider is that excised embryos can be extremely sensitive to desiccation. These occurrences can affect embryo germination and seedling development in culture, compromising the establishment of a cryopreservation protocol. Wen and Wang (2010) observed that cryopreserved embryos of four Sabal species that were excised prior to freezing showed lower emergence in vitro than the controls and concluded that this possibly resulted from differences in manipulations of the embryos, since preparation for cryopreservation requires extra procedures that cause a delay in embryo culture and might affect their viability.

Seedling emergence, as the marker for germination, was evaluated weekly up to 4 mo to calculate the final germination percentages for S. romanzoffiana ZEs (Fig. 1). The majority of seedlings obtained from control and cryopreserved ZE showed normal morphology, with a normal haustorium and roots, and, after 4 mo of culture in vitro, had fully expanded, bright green leaves (Fig. 3). As is generally the case for this species, germination of ZE was uneven and slow, even with the excision from the endocarp and growth in vitro under stimulating conditions. According to Baskin and Baskin (2014), the primary reason for this is that seeds of palm trees have small and immature embryos that must complete their development before germination can occur. Fruit bunches of queen palm contains fruits in different stages of maturation. It 


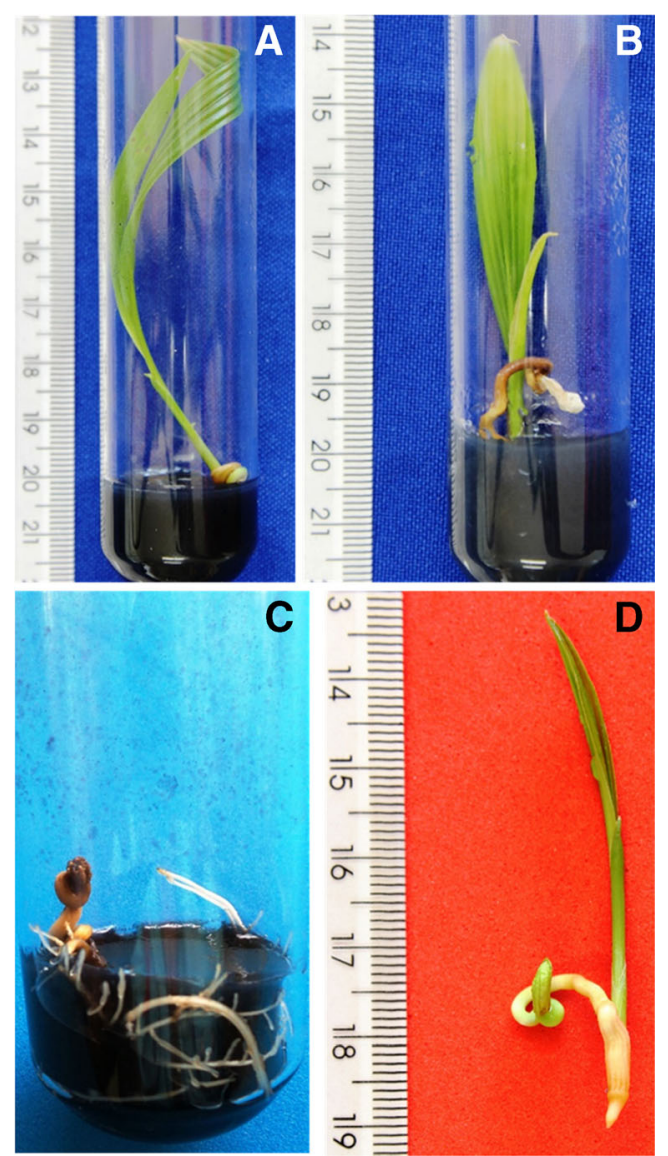

Figure 3. Seedlings originated from zygotic embryos of $S$. romanzoffiana germinated in vitro on WPM culture medium, after 4 mo of culture. (A) Normal seedlings with fully expanded leaves obtained from control zygotic embryos and $(B)$ from embryos stored in liquid nitrogen. Abnormal seedlings lacking $(C)$ the plumule or $(D)$ the root system.

is likely that fruits that are not fully mature are not capable of expressing the full germination potential of the species (Begnini et al. 2013; Oliveira et al. 2015; Garcia and Barbedo 2016).

Some seedlings showed an abnormal development of the root system or the haustorium (Fig. $2 C, D$ ). Damage to the root system occurred in ZE excised from endocarps containing the lowest water content (5.5\%) and was associated with water loss. Damage to the haustorium was observed in $\mathrm{ZE}$ excised from cryopreserved endocarps (Fig. $3 D$ ), as reported elsewhere in studies with other species of palms (Assy-Bah and Engelmann 1992; Steinmacher et al. 2007). In the present study, the final germination percentages, represented in Fig. 2, do not include the abnormal seedlings. Some of the ZE at the initial stages of germination in vitro showed fungal contamination. These embryos were discarded and were not included in the final germination percentages.

The excision and in vitro culture of ZE is a practical method for recovering cryopreserved seeds that might otherwise exhibit germination difficulties under laboratory conditions. The present study reports on a simple cryopreservation technique for S. romanzoffiana, involving partial desiccation of endocarps followed by direct freezing, slow thawing, and aseptic excision and culture in vitro of ZE. Excision and in vitro culture of embryos after cryopreservation is a simple technique that has been applied to many other plant species including C. nucifera (Assy-Bah and Engelmann 1992), V. merrilli and H. fosteriana (Chin et al. 1988), and Genipa americana (Santos and Salomão 2016), and it has been helpful in the assessment of viability and the regeneration of plantlets from cryopreserved seed samples (Pritchard et al. 2000).

Queen palm ZE excised from endocarps with different water contents $(5.5,7.95,10.52$, and $10.87 \%)$ were successfully cryopreserved, with high germination percentages ranging from 84 to $93 \%$. Cryopreservation in LN was the only treatment with a significant effect on the germination percentages of ZE, at the 0.05 probability level. The technique described here is simple and efficient, since a high percentage of cryopreserved ZE retained capacity to germinate and develop into whole, normal plantlets. However, to improve and validate this procedure, additional trials should be performed with larger numbers of endocarps, with endocarps from other regions and genetic backgrounds, and with endocarps at different maturation stages.

\section{Conclusions}

The results obtained in the present work provide novel evidence that cryopreservation is a feasible choice for the preservation of $S$. romanzoffiana germplasm to ensure long-term ex situ conservation of this species. This appears to be the first report of the cryopreservation of queen palm endocarps and in vitro rescue of the ZEs of this species.

\section{References}

Assy-Bah B, Engelmann F (1992) Cryopreservation of mature embryos of coconut (Cocos nucifera L.) and subsequent regeneration of plants. CryoLetters 13:117-126

Balesevic-Tubic S, Tatic M, Dordevic V, Nikilic Z, Dukic V (2010) Seed viability of oil crops depending on storage conditions. Helia 33:153160

Baskin JM, Baskin CC (2014) What kind of seed dormancy might palms have? Seed Sci Res 24:17-22

Begnini RM, de Silva FR, Castellani TT (2013) Fenologia reprodutiva de Syagrus romanzoffiana (Cham.) Glassman (Arecaceae) em Floresta Atlântica no sul do Brasil Reproductive phenology of Syagrus romanzoffiana (Cham.) Glassman (Arecaceae) in the Atlantic Forest in southern Brazil. Biotemas 26:53-60

Bernacci LC, Martins FR, dos Santos FAM (2008) Estrutura de estádios ontogenéticos em população nativa da palmeira Syagrus romanzoffiana (Cham.) Glassman (Arecaceae) [Structures of 
ontogenetic stages in a native population of Syagrus romanzoffiana (Cham.) Glassman (Arecaceae)]. Acta Bot Bras 22(1):119-130

Brancalion PHS, Novembre ADLC, Rodrigues RR (2011) Seed development, yield and quality of two palm species growing in different tropical forest types in SE Brazil: implications for ecological restoration. Seed Sci Technol 39:412-424

Brant RE, McKee GW, Cleveland RW (1971) Effect of chemical and physical treatment on hard seed of Penngift crownvetch. Crop Sci $11: 1-6$

Brazilian Ministry of Agriculture Livestock and Supply (2009) Regras para análise de sementes [Rules for seed testing). [Publisher unknown], Brasília

Busse WF (1930) Effect of low temperatures on germination of impermeable seeds. Bot Gaz 89:169-179

Chin HF, Krishnapillay B, Alang Z (1988) Cryopreservation of Veitchia and Howea palms embryos: non-development of the haustorium. CryoLetters 9:372-379

Chin HF, Krishnapillay B, Hor YL (1989) A note on the cryopreservation of embryos from young coconuts (Cocos nucifera var. Mawa). Pertanika 12:183-186

Engelmann F, Chabrillange N, Dussert S, Duval Y (1995) Cryopreservation of zygotic embryos and kernels of oil palm (Elaeis guineensis Jacq.) Seed Sci Res 5:81-86

Ferrari EAP, Colombo RC, de Faria RT, Takane RJ (2016) Cryopreservation of seeds of Encholirium spectabile Martius ex Schultes f. by the vitrification method. Rev Ciênc Agron 47:172177

Galetti M, Paschoal M, Pedroni F (1992) Predation on palm nuts (Syagrus romanzoffiana) by squirrels (Sciurus ingrami) in south-east Brazil. J Trop Ecol 8:121-123

Garcia VA, Barbedo CJ (2016) Estudo fenológico de Bactris gasipaes Kunth, Euterpe edulis Mart. e Syagrus romanzoffiana (Cham.) Glassman no Vale do Ribeira, SP, Brasil Phenological study of Bactris gasipaes Kunth, Euterpe edulis Mart. and Syagrus romanzoffiana (Cham.) Glassman in the Ribeira Valley, São Paulo State, Brazil. Hoehnea 43:135-149

Glassman SF (1987) Revision of the palm genus Syagrus Mart. and other genera in the Cocos Alliance. Ill Biol Monog 56:98

González-Benito ME, Aguilar N, Ávila T (2009) Germination and embryos rescue from Passiflora species seeds post-cryopreservation. CryoLetters 30:142-147

Goudel F, Shibata M, Coelho CMM, Miller PRM (2013) Fruit biometry and seed germination of Syagrus romanzoffiana (Cham.) Glassm. Acta Bot Bras 27:147-154

Grout BWW, Shelton K, Pritchard HW (1983) Orthodox behaviour of oil palm and cryopreservation of the excised embryo for genetic conservation. Ann Bot 52:381-384

Kaviani B (2011) Conservation of plant genetic resources by cryopreservation. Aust J Crop Sci 5:778-800

Lloyd G, McCown B (1981) Commercially feasible micropropagation of mountain laurel, Kalmia latifolia, by use of shoot tip culture. Intl Plant Propagators Soc 30:421-427
Lorenzi H (2002) Árvores brasileiras: manual de identificação e cultivo de plantas arbóreas do Brasil [Brazilian trees: manual for identification and cultivation of tree species of Brazil]. Instituto Plantarum, São Paulo, p 384

Lorenzi H, Souza HM, Medeiros-Costa JT, Cerqueira LSC, Behr N (1996) Palmeiras do Brasil: nativas e exóticas [Palm trees of Brazil: native and exotic]. Instituto Plantarum, São Paulo

McCullagh P, Nelder JA (1989) Generalized linear models. Chapman \& Hall, New York, p 513

Moreira MAC, Arrúa MP, Antunes AC, Fiuza TER, Costa BJ, Neto PW, Antunes SRM (2013) Characterization of Syagrus romanzoffiana oil aiming at biodiesel production. Ind Crop Prod 48:57-60

Murashige T, Skoog F (1962) A revised medium for rapid growth and bioassay with tobacco tissue cultures. Physiol Plant 15:473-497

N'Nan O, Borges M, Konan Konan J-L, Hocher V, Verdeil J-L, Tregear J, N'guetta ASP, Engelmann F, Malaurie B (2012) A simple protocol for cryopreservation of zygotic embryos of ten accessions of coconut (Cocos nucifera L.) In Vitro Cell Dev Biol Plant 48:160-166

Normah MN, Vengadasalam M (1992) Effects of moisture content on cryopreservation of Coffea and Vigna seeds and embryos. CryoLetters 13:199-208

Oliveira TGS, Jose AC, Ribeiro LM, Faria JMR (2015) Longevity and germination of Syagrus romanzoffiana (Arecaceae) seeds and its ecological implications. Rev Biol Trop 63:333-340

Pritchard HW, Beeby LA, Davies RI (2000) Role of embryo culture in the seed conservation of palms and other species. In: Razdan MK, Cocking EC (eds) Conservation of plant genetic resources in vitro. Volume 2: Applications and limitations. Science Publishers Inc, Barking, pp 89-138

Raja K, Palanisamy V, Selvaraju P (2003) Desiccation and cryopreservation of recalcitrant arecanut (Areca catechu L.) embryos. Plant Genet Resour Newsl 133:16-18

Reed BM (2008) Plant cryopreservation: a practical guide. Springer, New York

Salomão AN (2002) Tropical seed species' responses to liquid nitrogen exposure. Braz J Plant Physiol 14:133-138

Santos IRI, Salomão AN (2016) Viability assessment of Genipa americana L. (Rubiaceae) embryonic axes after cryopreservation using in vitro culture. Intl J Agron 2016:1-6. doi:10.1155/2016/ 7392710

Steinmacher DA, Saldanha CW, Clement CR, Guerra MP (2007) Cryopreservation of peach palm zygotic embryos. CryoLetters 28: 13-22

Sturião WP, Landgraf PRC, Rosa TP (2012) Avaliação da qualidade de sementes de palmeira jerivá pelo teste de raios $\mathrm{X}$ Evaluation of queen palm seeds quality by the X-ray test. Semina Ciênc Agrar 33:213-218

Wen B, Wang R (2010) Pretreatment incubation for culture and cryopreservation of Sabal embryos. Plant Cell Tissue Organ Cult 102:237243

Zaid A, Tisserat B (1984) Survey of morphogenetic potential of excised palm embryos in vitro. Crop Res 24:1-9 